\title{
Electrolytes in vaginal fluid during the menstrual cycle of coitally active and inactive women
}

\author{
G. Wagner and R. J. Levin* \\ Institute of Medical Physiology B, University of Copenhagen, Panum Institute, \\ 2200 Copenhagen N, Denmark, and \\ *Department of Physiology, University of Sheffield, Sheffield S10 2TN, U.K.
}

\begin{abstract}
Summary. Vaginal fluid was collected on tampons self-inserted for $4 \mathrm{~h}$ daily during the menstrual cycles of coitally active, coitally inactive, ovulatory and non-ovulatory women. The daily hourly rate of fluid collected and its concentrations of $\mathrm{Na}^{+}, \mathrm{K}^{+}$, $\mathrm{Cl}^{-}$and $\mathrm{Ca}^{2+}$ were assessed. The fluid revealed a characteristic composition throughout all the menstrual cycles of 'high potassium-low sodium concentrations' compared to plasma, but no characteristic changes with the stage of the cycle. Occasional transient increases and decreases in $\mathrm{Na}^{+}$and $\mathrm{Cl}^{-}$concentrations were observed, usually closely correlated with one another. Transient changes in $\mathrm{K}^{+}$also occurred but these were not always correlated with other ions. In 9 cycles from 7 subjects the mean \pm s.e.m. levels (in $\mathrm{mmol} / \mathrm{kg}$ fluid) of $\mathrm{Na}^{+}(82 \pm 4), \mathrm{K}^{+}(30 \pm 2)$ and $\mathrm{Cl}^{-}(79 \pm 4)$ in the first 7 days of the cycles were not significantly different from the $\mathrm{Na}^{+}(75 \pm 5), \mathrm{K}^{+}(30 \pm 2)$ and $\mathrm{Cl}^{-}(72 \pm 7)$ concentrations of the last 7 days of the cycles. This suggests that the differences in hormonal balance between the two phases of the menstrual cycle do not influence the ionic levels of vaginal fluid. The concentration of $\mathrm{Ca}^{2+}$ in 3 ovulating subjects varied between 1 and $5 \mathrm{mmol} / \mathrm{kg}$ fluid and often appeared to be inversely correlated with the amount of fluid collected.
\end{abstract}

\section{Introduction}

Although the ionic compositions of human cervical, uterine, oviductal and follicular fluids have been published (Table 1) no data exist on the ionic constitutents of human vaginal fluid, despite the fact that it is the medium into which the semen is first ejaculated.

This paper documents the major ions $\left(\mathrm{Na}^{+}, \mathrm{K}^{+}, \mathrm{Cl}^{-}\right.$and $\left.\mathrm{Ca}^{2+}\right)$ in the vaginal fluid of coitally active and inactive healthy women and describes the changes that take place in their concentration during the menstrual cycles.

\section{Materials and Methods}

The studies with volunteers were undertaken at the University of Copenhagen and at the University of Sheffield. The various details of these subjects are given in Table 2. Each woman was issued with a collection of sequentially numbered plastic vials fitted with a snap-on airtight lid. Every vial contained a commercial tampon (Tampax) that had been cut crossways in half after extrusion from its cardboard container. The half with the free string attached was used, the container and the other half being discarded. Each half tampon was weighed and then weighed again with the numbered vial. A chart was issued to each subject to record the data, day of menstrual cycle, time of insertion and removal of tampon, any coital, sexual or other activities or 
Table 1. Potassium and sodium content of various human genital fluids/secretions

\begin{tabular}{|c|c|c|c|c|}
\hline \multirow[b]{2}{*}{ Fluid } & \multirow{2}{*}{$\begin{array}{l}\text { Reproductive } \\
\text { condition }\end{array}$} & \multicolumn{2}{|c|}{$\begin{array}{c}\text { Ion conc. } \\
(\mathrm{mmol} / \mathrm{l} \text { or } \mathrm{mmol} / \mathrm{kg})\end{array}$} & \multirow[b]{2}{*}{ Reference } \\
\hline & & $\mathbf{K}^{+}$ & $\mathrm{Na}^{+}$ & \\
\hline $\begin{array}{l}\text { Serum } \\
\text { Ovarian follicle }\end{array}$ & & $\begin{array}{l}3 \cdot 5-5 \cdot 5 \\
4 \cdot 4 \pm 0 \cdot 2 \\
6\end{array}$ & $\begin{array}{l}133-150 \\
124 \pm 3 \\
157\end{array}$ & $\begin{array}{l}\text { Lippes et al. (1972) } \\
\text { Shalgi et al. }(1972) \\
\text { Edwards (1973) }\end{array}$ \\
\hline Oviduct & $\begin{array}{l}\text { Proliferative } \\
\text { Secretory }\end{array}$ & $\begin{array}{l}10 \pm 2 \\
8 \pm 1\end{array}$ & $\left.\begin{array}{l}140 \pm 3 \\
140 \pm 2\end{array}\right\}$ & Lippes et al. (1972) \\
\hline Uterus & $\begin{array}{l}\text { Proliferative } \\
\text { Proliferative } \\
\text { Secretory } \\
\text { Proliferative } \\
\text { Secretory }\end{array}$ & $\begin{array}{l}6-9 \\
18 \pm 3 \\
34 \pm 3 \\
4 \\
3\end{array}$ & $\left.\begin{array}{l}128-158 \\
124 \pm 3 \\
108 \pm 4 \\
106 \\
130\end{array}\right\}$ & $\begin{array}{l}\text { Edwards et al. (1968) } \\
\text { Clemetson et al. (1973) } \\
\text { Kar et al. (1968) }\end{array}$ \\
\hline Cervix & $\begin{array}{l}\text { During cycle } \\
\text { During cycle }\end{array}$ & $\begin{array}{l}3-21 \\
15-48\end{array}$ & $\begin{array}{l}100-175 \\
72-195\end{array}$ & $\begin{array}{l}\text { Lebech et al. }(1970) \\
\text { Kopito et al. }(1973)\end{array}$ \\
\hline Vagina & $\begin{array}{l}\text { Proliferative } \\
\text { Secretory }\end{array}$ & $\begin{array}{l}30 \pm 2 \\
30 \pm 2\end{array}$ & $\left.\begin{array}{l}82 \pm 4 \\
76 \pm 5\end{array}\right\}$ & Present study \\
\hline $\begin{array}{l}\text { Seminal plasma } \\
\text { Seminal vesicles } \\
\text { Prostate (resting) }\end{array}$ & Range & $\begin{array}{l}23 \\
18 \\
29-61 \\
48\end{array}$ & $\begin{array}{l}117 \\
103 \\
149-158 \\
153\end{array}$ & $\begin{array}{l}\text { Spector (1956) } \\
\text { Huggins et al. (1942) } \\
\text { Huggins (1945) } \\
\text { Spector (1956) }\end{array}$ \\
\hline
\end{tabular}

Values are ranges or mean \pm s.e.m.

Table 2. Details of the subjects used

\begin{tabular}{cclcl}
\hline Subject & $\begin{array}{c}\text { Age } \\
\text { (years) }\end{array}$ & $\begin{array}{c}\text { Contraception } \\
\text { employed }\end{array}$ & Parity & Country \\
\hline 1 & 33 & IUD (Cu 7) & 2 & England \\
2 & 40 & IUD (Dalkon Shield) & 2 & England \\
3 & 24 & None & 0 & England \\
4 & 24 & None & 0 & England \\
5 & 31 & Steroid (Lynoestrenol) & 0 & Denmark \\
6 & 39 & None & 0 & Denmark \\
7 & 42 & Diaphragm & 2 & Denmark \\
9 & 32 & None & 0 & Denmark \\
10 & 34 & None & 0 & Denmark \\
\hline
\end{tabular}

comments relevant to experiment (swimming, baths, urination, etc.). The subjects in Sheffield were issued with an oral thermometer to record their basal body temperature (BBT) each morning before rising. Two of the subjects experienced difficulty in reading the thermometer and the data recorded were judged unreliable. Three of the subjects (Nos 7,9 and 10) had venous blood samples taken during their follicular and luteal phases to ascertain the levels of plasma progesterone (Spona, Schneider \& Wacheck, 1978). Presumptive evidence of ovulation was assumed in the cycles in which serum progesterone levels in the luteal phase exceeded $3 \mathrm{ng}$ progesterone/1 (Israel, Mishell, Stone, Thorneycroft \& Moyer, 1972). The first day of the subject's menses was designated Day 1 of the cycles.

The subjects were told to wait until the end of their menses and then to insert, each day, a fresh tampon, in serial order into their vagina leaving the string outside. The tampon was to be left for 4-5 h. At the timed removal, the tampon was to be placed immediately into its vial and the air-tight sealing lid snapped on. Whenever possible, the vials were to be stored in a refrigerator before collection. The insertion and removal of the tampon was to be accomplished at approximately the same time of the day over the cycle. On arrival at the laboratories, each vial was weighed and the weight of vaginal fluid collected was obtained by subtraction and the $\mathrm{g} / \mathrm{h}$ by reference to the duration of collection. The vials were opened and $20 \mathrm{ml}$ distilled water were added. A plunger consisting of a perforated plastic disc fitted onto a stainless-steel rod was access 
inserted into the vial and the fluid-expanded tampon was compressed approximately 20 times to make certain the water extracted all the absorbed vaginal secretion from the tampon. The water was then left in contact with the tampon for approximately $2 \mathrm{~h}$. The fluid was then drained off and centrifuged until the supernatant was free of cellular debris. Samples of this supernatant were analysed for $\mathrm{Na}^{+}$and $\mathrm{K}^{+}$by flame photometry (IL343 Digital flame photometer in Copenhagen; Corning Flame Photometer 430 in Sheffield), for $\mathrm{Ca}^{2+}$ by flame photometry (IL343 Digital flame photometer in Copenhagen) and for $\mathrm{Cl}^{-}$by electrometric titration (CMT Chloride Titrator, Radiometer, in Copenhagen; Cotlove Chloridometer in Sheffield).

In the subjects that were sexually active practically all coital activity took place between 19:00 and 00:01 h. As most of the women inserted their tampons during the morning, a minimum of $7 \mathrm{~h}$ and usually much more had elapsed before the tampon came into contact with any residual male fluids.

\section{Control experiments}

Features of the collection and analytical techniques were assessed in preliminary control experiments. To ascertain the possible error involved in assuming that the increase in weight of the tampons after insertion and removal was mainly due to vaginal fluid rather than solids (mucus, shed cells, bacteria etc.), tampons were self inserted into the vagina by 9 volunteers on different days of their cycles and the amount of solids per $100 \mathrm{~g}$ secretion collected was obtained by drying the tampons at $100^{\circ} \mathrm{C}$ for approximately $12-24 \mathrm{~h}$. The amount of vaginal fluid collected was $0.33 \pm 0.05$ (s.e.m.) $\mathrm{g} / \mathrm{h}$ and the percentage dry weight was $7.01 \pm 0.64$ (range 4-10\%). The measured ion concentrations should therefore be slightly higher than the actual value for the weight of secretion collected. Although this error is small and well within the range of variation of the changes of ion concentration on a day-to-day basis, the ionic concentrations have been reported as $\mathrm{mmol} / \mathrm{kg}$ vaginal fluid rather than the less accurate $\mathrm{mmol} / \mathrm{l}$ vaginal fluid.

When control tampons were extracted with water by the same techniques as used for inserted tampons, $\mathrm{Na}^{+}$and $\mathrm{K}^{+}$concentrations were $<1 \mathrm{mmol} / 1$ and the tampon blank was taken as zero. Addition of $154 \mathrm{mmol} \mathrm{NaCl} / \mathrm{l}$ or $154 \mathrm{mmol} \mathrm{KCl} / 1$ to a tampon and subsequent extraction with water showed that full recovery of the ions could be obtained and that no binding of the $\mathrm{Na}^{+}$or $\mathrm{K}^{+}$occurred. To assess whether the extraction of the tampons with distilled water could cause disruption of any intact, shed epithelial cells, a tampon was inserted into a subject's vagina for 4 $h$, removed and cut in half. One half was extracted immediately in distilled water while the other was extracted with isotonic sucrose $(304 \mathrm{mmol} / \mathrm{l})$. There were no significant differences for the two extraction procedures. To check whether storage of the inserted tampons in the freezer compartment of commercial fridges and subsequent thawing could cause increased cellular lysis (and hence alter the ionic levels), tampons were inserted into a subject's vagina for $3 \mathrm{~h}$ and weighed immediately after removal before being cut into two approximately equal sections. One half was extracted in isotonic sucrose while the other was stored overnight in a sealed vial in the freezer compartment of a refrigerator. After removal and thawing at room temperature in the morning, it too was extracted with isotonic sucrose. The results obtained from 2 experiments indicated that the ionic concentrations of $\mathrm{Na}^{+}, \mathrm{K}^{+}$and $\mathrm{Cl}^{-}$of the vaginal fluid from frozen and fresh tampons were very similar and that the small differences seen for $\mathrm{K}^{+}$concentrations (probably the best index of increased cellular lysis) were well within the limits of sampling error for a divided tampon collecting fluid from different parts of the vagina.

\section{Results}

\section{Subject 1}

Cycle 1. In this cycle (Text-fig. 1a) the BBT was monophasic and did not give a clear indication of an increased temperature in the second phase of the cycle. However the subject noted a large globule of vaginal mucus on Day 15 and experienced abdominal pains on Day d 7 , 
(a) Subject 1: Cycle 1

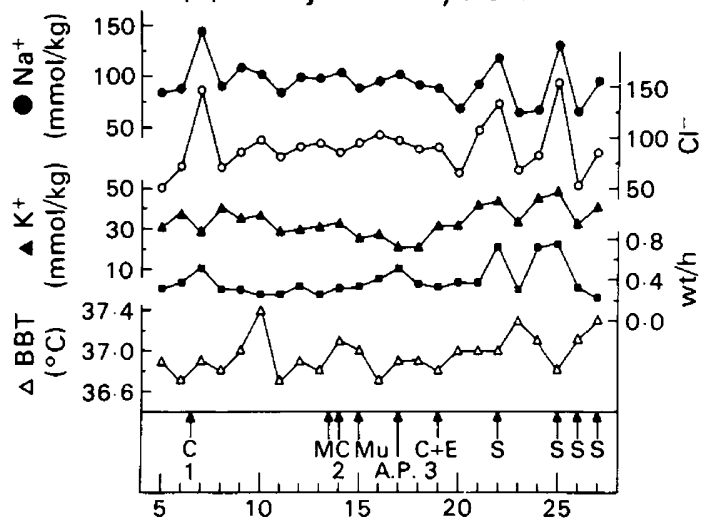

(b) Subject 1: Cycie 2

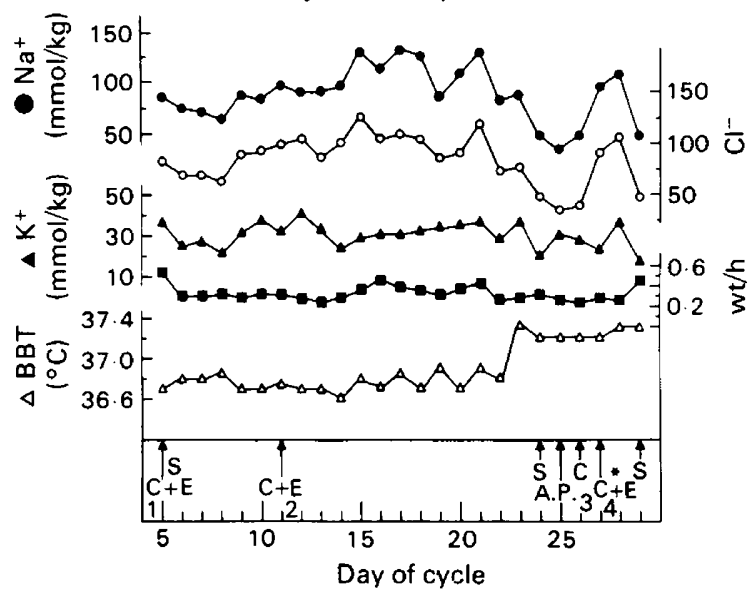

(d) Subject 3: Cycle 1

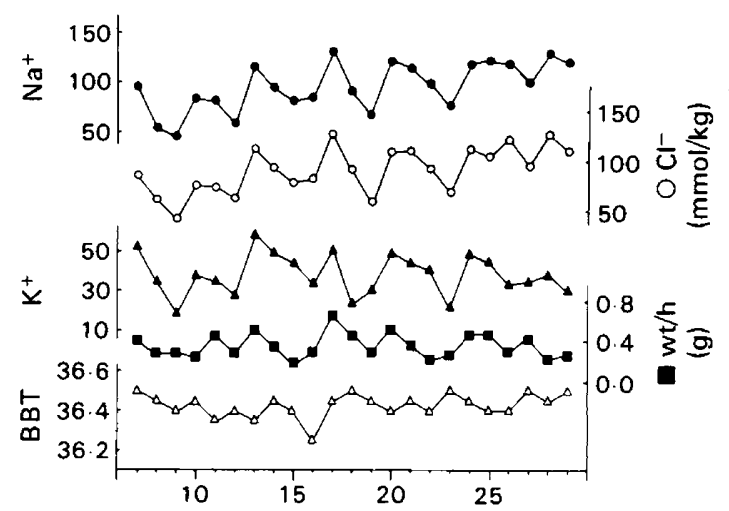

(c) Subject 2: Cycle 1

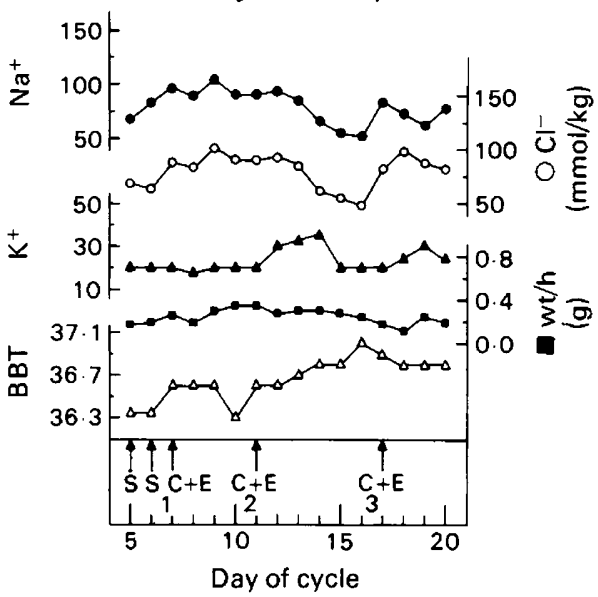

Text-fig. 1. Results obtained for measurements of $\mathrm{Na}^{+}(\mathbf{O}), \mathrm{Cl}^{-}(\mathrm{O}), \mathrm{K}^{+}(\mathbf{\Delta})$, basal body temperature $(\triangle)$, and amount of vaginal fluid collected $(\boldsymbol{G})$ from women. $\mathbf{C}=$ coitus without semen deposition into the vagina; $C+E=$ coitus plus ejaculation into the vagina; $\mathbf{M}=$ masturbation; $\mathbf{M u}=$ muscus; $\mathbf{A P}=$ abdominal pain; $\mathbf{S}=$ slight blood spotting.

manifestations experienced in previous ovulatory cycles. The amount of vaginal secretion collected during the cycle varied little except for a sharp peak on Day 22 and one on Days 24 and 25 . The subject was sexually active, experiencing coitus with and without ejaculation, and orgasm induced by masturbation. The sodium and chloride concentrations displayed sharp peaks on Day 7 and on Days 22 and 25, reaching very high levels but varied little at other times. The concentration of $\mathrm{K}^{+}$increased slowly from Days 19 to 25 . There was general correspondence between the various peaks recorded.

Cycle 2. In this cycle (Text-fig. 1b) the BBT showed a marked and sustained elevation on Day 23 and abdominal pains were experienced on Day 25. The weight of vaginal fluid varied little throughout the cycle. The $\mathrm{Na}^{+}$and $\mathrm{Cl}^{-}$concentrations followed each other closely, both displaying a decrease from Day 21 to a minimum at Day 25, and then a peak over the last few days of the cycle. The $\mathrm{K}^{+}$concentration showed only small variations throughout the cycle. The subject was coitally active during the cycle. 


\section{Subject 2}

The BBT of this sexually active subject showed a slowly sustained elevation for the last half of the cycle (Text-fig. 1c). The amount of fluid collected showed only minor variations with no major peaks. The $\mathrm{Na}^{+}$and $\mathrm{Cl}^{-}$concentrations followed one another closely, both having a sustained decrease to a minimum at Day 16 followed by a recovery to previous levels. The $\mathrm{K}^{+}$ concentration was stable except for a clear elevation during Days 12, 13 and 14. Subject was coitally active.

\section{Subject 3}

The BBT exhibited a clear fall at Day 16 with a subsequent rise on the following day, but the rise was not maintained and the temperature subsequently oscillated (Text-fig. 1d). There were small peaks in the amount of fluid collected, the largest being on Day 17 . The $\mathrm{Na}^{+}, \mathrm{Cl}^{-}$and $\mathrm{K}^{+}$ concentrations showed marked oscillations with an approximate 4-day periodicity. The subject was coitally inactive during this cycle.

\section{Subject 4}

The amount of fluid collected showed two increases around Days 15-16 and Day 18 (Text-fig. 2a). The $\mathrm{K}^{+}$concentration displayed small peaks in the first 10 days of the cycle which subsided leaving a slightly lower level in the last 8 days. The changes in $\mathrm{Na}^{+}$and $\mathrm{Cl}^{-}$ concentration were closely correlated, both showing sustained increase to a peak around Day 18 and then a return to the previous lower levels. No coital activity took place during the cycle.

\section{Subject 6}

There were small changes in the amount of fluid collected until a large increase the day before menstruation began (Text-fig. 2b). The $\mathrm{K}^{+}$concentration revealed 2 small peaks on Days 13 and 19, while the $\mathrm{Na}^{+}$and $\mathrm{Cl}^{-}$concentrations displayed sustained increases over Days 12-16. No coital activity was experienced during the cycle.

\section{Subject 7}

The amount of fluid collected in Cycle 1 was high on Day 5 and slightly increased on Days 8-10 but there was little other change (Text-fig. 2c). There were 2 small peaks of $\mathrm{K}^{+}$ concentration on Days 8 and 11 and a very large increase on the day before menstruation started. This large increase in $\mathrm{K}^{+}$correlated with dramatic rises in the levels of $\mathrm{Na}^{+}$and $\mathrm{Cl}^{-}$, concentrations of which were also high on Days 8-11. The subject was sexually active.

\section{Subjects 7,9 and 10}

Plasma progesterone concentrations were estimated in the first and last parts of the cycles of these women to ascertain whether a functional corpus luteum was present. A marked elevation, well above the $3 \mathrm{ng} / \mathrm{l}$ needed to give a secretory endometrium (Israel et al., 1972), was recorded in all 3 subjects and these cycles were therefore presumed to be ovulatory.

Subject 7. In this cycle (Text-fig. 3a) there was a 5 -fold increase in fluid collected on Day 19 and this peak was followed closely by peaks in the $\mathrm{K}^{+}$and $\mathrm{Cl}^{-}$concentrations but not of $\mathrm{Na}^{+}$. The $\mathrm{Ca}^{2+}$ concentration decreased as the amount of fluid increased. A small peak in all the monovalent ions was observed on Day 11 but the $\mathrm{Ca}^{2+}$ levels were unaltered. 
(a) Subject 4: Cycle 1

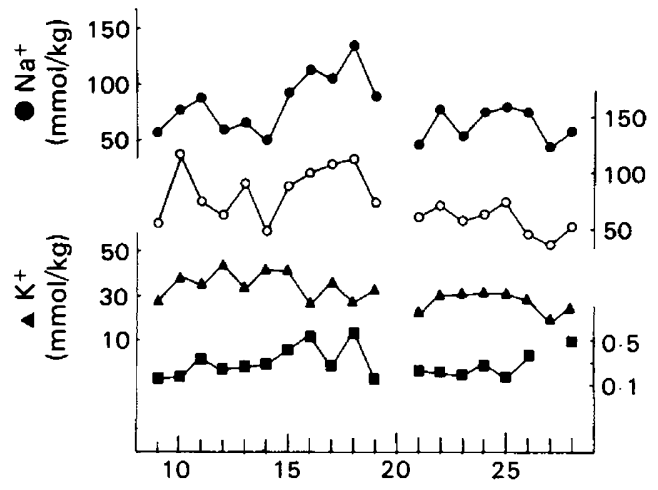

(c) Subject 7: Cycle 1
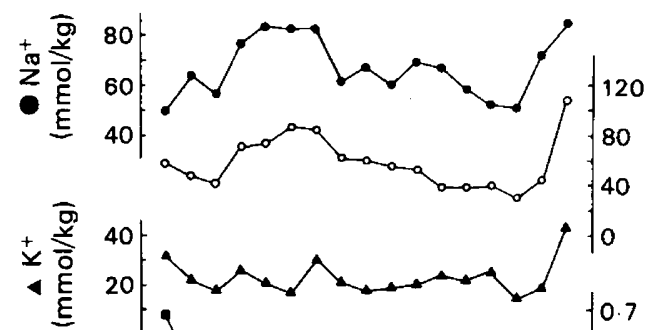

$\underline{\varepsilon}$

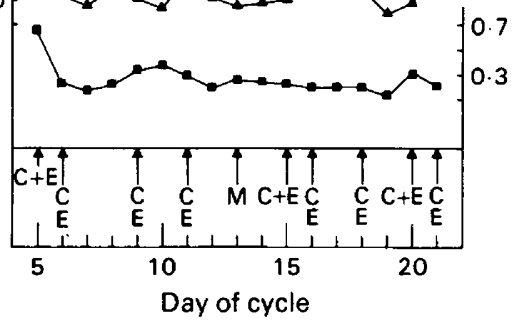

(b) Subject 6: Cycle 1

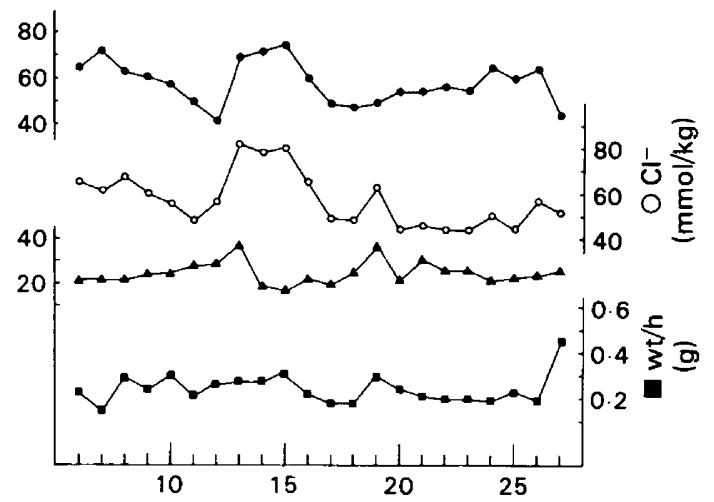

(d) Subject 5: Cycle 1

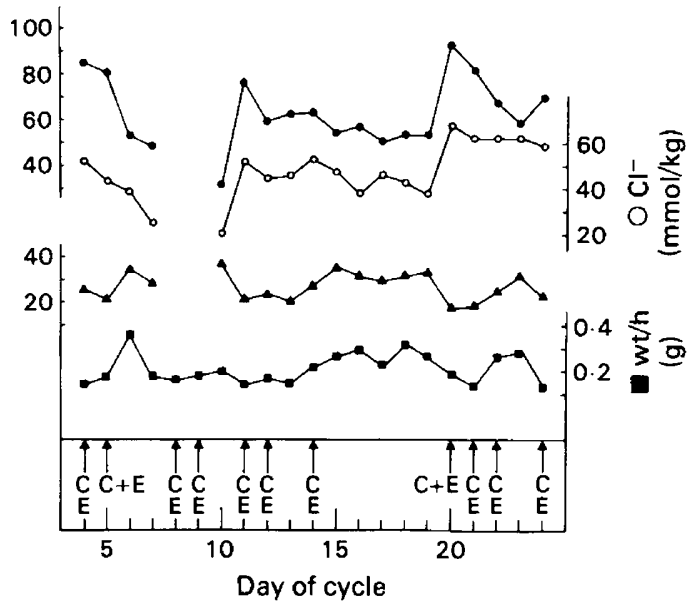

Text-fig. 2. Results as in Text-fig. 1 for 4 other women.

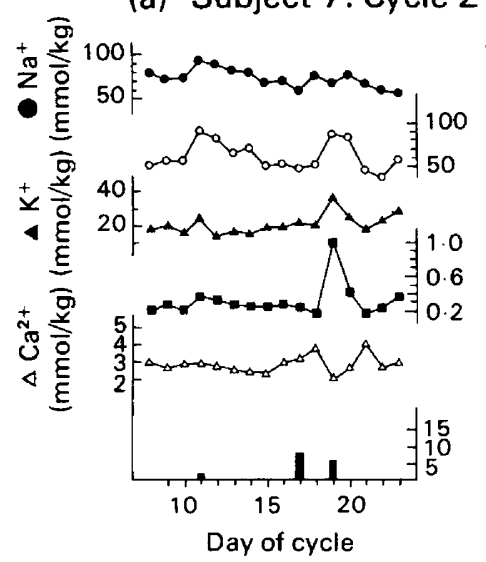
(a) Subject 7: Cycle 2
(b) Subject 9

(c) Subject 10
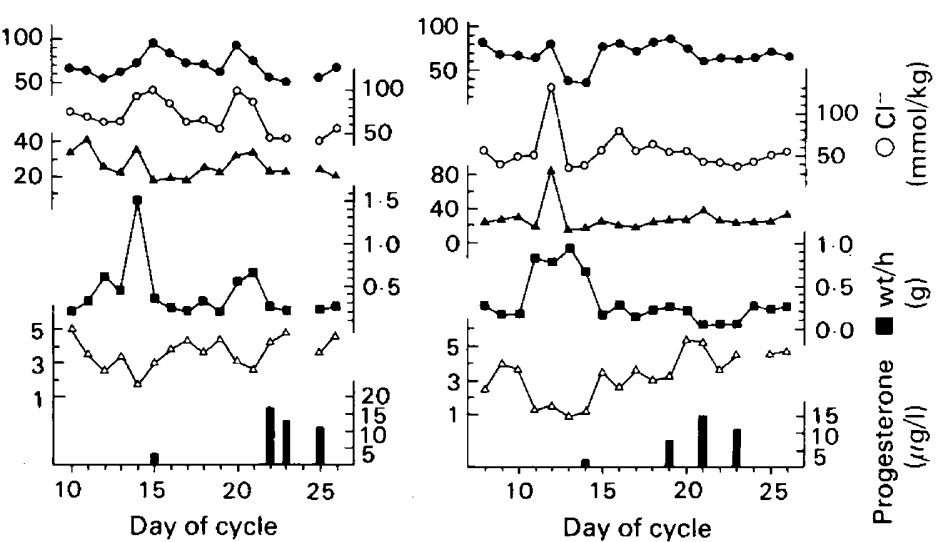

Text-fig. 3. Measurements of ions $\left(\mathrm{Na}^{+}, \mathrm{K}^{+}, \mathrm{Cl}^{-}\right.$and $\left.\mathrm{Ca}^{2+}\right)$, amount of vaginal fluid collected and plasma progesterone concentrations in 3 women. Coitus with ejaculation $(\mathrm{C}+\mathrm{E})$ took place on Days 8, 10, 12, 15, 18, 19, 20 and 23 for Subject 7; Days 16, 19 and 21 for Subject 9; and Days 10, 12, 14, 16, 18, 20 and 24 for Subject 10. Masturbation to orgasm occurred in Subject 10 on Day 24. In (b) the tampon was lost on Day 24. 
Subject 9. A large peak in the fluid collected on Day 14 was observed with a much smaller peak on Days 20-21 (Text-fig. 3b). The increases were matched by peaks in $\mathrm{Na}^{+}, \mathrm{K}^{+}$and $\mathrm{Cl}^{-}$ and decreases in $\mathrm{Ca}^{2+}$ concentration.

Subject 10. A large maintained increase in fluid was observed on Days 10-13 concomitant with increases in the $\mathrm{Na}^{+}, \mathrm{K}^{+}$and $\mathrm{Cl}^{-}$concentrations and a decrease in the $\mathrm{Ca}^{2+}$ levels (Text-fig. 3c).

\section{Subject 5}

This subject was taking a steroid formulation, lynoestrenol, as a contraceptive precaution. The initial concentrations of $\mathrm{Na}^{+}$and $\mathrm{Cl}^{-}$were high, then fell to low values during the next few days (Text-fig. 2d). A peak at Day 10 was followed by fairly stable concentrations until a large increase on Day 19. The $\mathrm{K}^{+}$concentration varied over the cycle and tended to decrease when the $\mathrm{Na}^{+}$and $\mathrm{Cl}^{-}$concentrations increased. The amount of fluid produced varied little for most of the cycle except for a peak on Day 6 and small increases on Days 18, 22 and 23. None of these was correlated with increases in $\mathrm{Na}^{+}$or $\mathrm{Cl}^{-}$. The subject was sexually active.

\section{Ion concentrations during the first and last 7 days of the cycle}

The concentrations of $\mathrm{Na}^{+}, \mathrm{K}^{+}$and $\mathrm{Cl}^{-}$in 9 menstrual cycles from 7 of the subjects (mean \pm s.e.m. concentrations expressed in $\mathrm{mmol} / \mathrm{kg}$ ) of $\mathrm{Na}^{+}, \mathrm{Cl}^{-}$and $\mathrm{K}^{+}$were $82 \pm 4,78.8+4$ and $29.6 \pm 2$, respectively, in the first 7 days after the end of menstruation and $75.5 \pm 5,72.3 \pm 6$ and $29.5 \pm 2$, respectively, in the 7 days before the start of the next menstruation. None of the values was significantly different $(P>0.05$, unpaired Student's $t$ test).

\section{Discussion}

\section{Ionic concentrations of vaginal fluid}

The data reveal for the first time that the vaginal fluid of women has a distinct ionic characteristic throughout the menstrual cycle regardless of whether there is extensive coital activity with many ejaculates deposited into the vagina (Subject 7), no coital activity (Subjects 3 , 4 and 6), ovulation (Subjects 1, 2, 7, 9 and 10) or possible (Subjects 1 and 3) or no (Subject 5) ovulation. The 'basal' sodium concentration, approximately $70-80 \mathrm{mmol} / \mathrm{kg}$, is well below the 95\% range measured in human plasma or serum (132-151 mmol/l serum: Documenta Geigy, 1973). While there were occasional peaks of $100 \mathrm{mmol} / \mathrm{kg}$ fluid, these increases were transient lasting only 1 day. The 'basal' concentration of chloride, like that of sodium, was usually 70-80 $\mathrm{mmol} / \mathrm{kg}$ fluid, also below the $95 \%$ range observed in human plasma or serum (101-111 mmol/l: Documenta Geigy, 1973). Transient peaks with concentrations up to $100 \mathrm{mmol} / \mathrm{kg}$ fluid occurred occasionally. In most subjects the variations in the concentrations of sodium and chloride followed one another very closely, suggesting some type of linkage, although sometimes the changes were out of phase. The concentration of potassium in the vaginal secretion varied between 20 and $40 \mathrm{mmol} / \mathrm{kg}$ (with occasional daily peak values as high as $80 \mathrm{mmol} / \mathrm{kg}$ ). These values represent concentrations of potassium between 5 and 8 times that found in normal serum (95\% range, 3.6-5.2 mmol/l: Documenta Geigy, 1973). The level of calcium measured in the 3 women whose progesterone levels indicated that ovulation took place (Subjects 7, 9 and 10) varied between 1 and $5 \mathrm{mmol} / \mathrm{kg}$ secretion and appeared to be inversely related to the amount of fluid, the greater the amount collected the lower its concentration of $\mathrm{Ca}^{2+}$. The range found in the vaginal secretions is within the $95 \%$ range measured in normal plasma or serum $(4 \cdot 8-5 \cdot 6$ $\mathrm{mmol} / \mathrm{l}$ : Documenta Geigy, 1973). While it is clear that the 'low sodium-high potassium' is not due to contamination with human ejaculate but is a property of the vaginal fluid per se sexual 
arousal created by coitus does induce the formation on the surface of the vagina of a lubricative fluid that has the ionic characteristics of a modified transudate of plasma and this would obviously raise the sodium concentration of the vaginal contents (Wagner \& Levin, 1978a). However, examination of the relationship between coitus, $\mathrm{Na}^{+}$concentrations and the amount of fluid collected for the various cycles does not indicate any obvious correlation. This may be a consequence of the slow reabsorption of fluid by the vagina after coitus (Odeblad, 1964) due to its active ion transfer (Levin \& Wagner, 1978). Another possibility is that as the sexually induced changes are small they are not easy to identify amidst the spontaneous, much larger variations observed throughout the cycle.

The low sodium-high potassium of vaginal fluid is very different from that of plasma, but the high $\mathrm{K}^{+}$is reported in other genital fluids (see Table 1). Nelson (1967) has suggested that the high levels of potassium and the suspected low $\mathrm{PO}_{2}$ values of the male genital fluids might inhibit the motility and metabolism of the stored spermatozoa. The resting vagina also has a low $P_{\mathrm{O}_{2}}$ which is greatly increased by sexual arousal (Wagner \& Levin, 1978b). However, the relationship between high potassium concentrations and human sperm motility is unclear and controversial (see Sheth \& Rao, 1962; Battersby \& Chandler, 1977). Guerin \& Czyba (1979) reported that neither motility nor mean velocity of human spermatozoa incubated in fluids containing $65 \mathrm{mM} \mathrm{Na}{ }^{+}$or $\mathrm{K}^{+}$were affected compared to controls. Only when the potassium concentration was raised to $125 \mathrm{~mm}$ and the sodium dropped to $5 \mathrm{~mm}$ was a significant reduction in motility observed.

Other roles that the high potassium-low sodium may play are in hastening capacitation (Toyoda \& Chang, 1974) and in creating a favourable environment for the microflora of the vagina, especially Doderlein's bacillus. This lactobacillus creates the high acidity in the vagina by its production of lactic acid from vaginal glycogen (Brown, 1978). The low $\mathrm{pH}$ created protects the vagina from being colonized by pathogens. The lack of any difference in concentrations of $\mathrm{Na}^{+}, \mathrm{K}^{+}$and $\mathrm{Cl}^{-}$in the first 7 days and the last 7 days of the menstrual cycles suggests that the changing hormonal balance between the proliferative and luteal phases does not significantly affect the ionic levels of vaginal fluid.

\section{Variations in the amount of vaginal fluid}

During the intermenstruum the secretions that constitute the 'vaginal fluid' can include (1) peritoneal fluid, (2) follicular fluid, (3) uterine fluid, (4) cervical fluid, (5) secretions from Bartholin's and Skene's glands, and (6) vaginal fluid per se, together with any shed cells, leucocytes, bacteria etc. from the vagina and higher up the genital tract. It is also possible that small amounts of urine can contaminate the vagina (Wagner \& Levin, 1978a).

Odeblad (1964) reported that in his 5 subjects, solids made up 29-51\% of the vaginal secretion. In 9 subjects that we studied, solids made up only some $7 \%$ of the secretions collected, with the maximum value of $10 \%$ only observed in one subject. We have no explanation for the great difference between the two studies. Of the various fluids and secretions that make up the vaginal secretion, quantitatively the most important should be cervical fluid and vaginal fluid per se. Surprisingly, although a few measurements have been made of the amount of vaginal fluid in different hormonal conditions by swabbing out the vagina with weighed tampons (see Wagner $\&$ Levin, 1978a, for review), no quantitative measurements of vaginal fluid throughout individual menstrual cycles have been published. Dusitsin, Gregoire, Johnson \& Rakoff (1967) produced a composite graph of the variation in the amount of vaginal secretion during the pooled menstrual cycle days of 35 female prisoners aged 16-60 years, but each point represented the average amount collected for that day from an unknown number of subjects and no data are given as to whether the subjects were ovulating or masturbated during the $18 \mathrm{~h}$ that the tampon was present in the vagina. Such sexual activity could have increased the amount of vaginal fluid collected (Wagner \& Levin, 1978a). The cervices of the subjects were capped so the secretions collected 
could only have come from the vagina per se. It was claimed that the cross-sectional data showed a significant decrease in vaginal secretions around Days 12-16. The average hourly amount of secretion from the graph of Dusitsin et al. (1967) gave a value of $0.11 \mathrm{~g} / \mathrm{h}$. The only other study of relevance is a preliminary report by Polishuk \& Ron (1976). They inserted small cylinders of a hydrophilic polymer overnight into the vaginas of 3 presumptively ovulating women for up to 5 nights before and 5 nights after the measured mid-cycle LH peak. The cylinder diameters increased after taking up water; maximum diameters were achieved 1 day before, at and 1 day after the LH peaks in the 3 women, suggesting that the vaginal fluid has its highest fluid content around the mid-cycle LH peak. Previous studies by Pommerenke (1946) had shown that human cervical mucus had its highest water content around mid-cycle so the cylinders will be imbibing this fluid as well as vaginal fluid per se. It is commonly accepted that, because cervical secretion is stimulated by the rising plasma oestrogen level, 'vaginal fluid' (vulvar wetness) appears increased around mid-cycle. This is the basis of the so-called ovulation method of using vulvar observations as an index of fertility (Hilgers \& Prebil, 1979). The increases in cervical secretion should be reflected in an increased weight of the vaginal fluid collected by tampons during ovulatory cycles. Igarashi (1954) reported a mean of 307 and a maximum of 708 mg mucus in the ovulation phase. Among our subjects, presumptive ovulatory cycles were observed for Subjects, 7, 9 and 10 (progesterone concentration) and Subject 2 (significant BBT shift). The BBT in Cycle 1 of Subject 1 and Subject 3 did not reveal the clear-cut classical dip and elevation around mid-cycle, but many observations on BBT have shown that these criteria, while useful to indicate ovulatory cycles, by their absence do not prove that ovulation has failed to occur. In $12 \%$ of normal cycles, ovulation occurs without corresponding changes in BBT (Johansson, Larsson-Cohn \& Gemzell, 1972). Clear increases in the amount of vaginal fluid around mid-cycle, equal to or greater than any increase in other parts of the cycle, were observed in Subjects 4, 9 and 10. The large increase in weight observed for Subject 7 on Day 19 would appear to have occurred in the luteal phase after ovulation. From our limited number of subjects, therefore, quantitative measurements of changes in the amount of vaginal fluid are unlikely to be a useful index for the assessment of ovulation. The reabsorption of fluid by the vagina (Odeblad, 1964; Wagner \& Levin, 1978a) may be an important influencing factor. The absolute figures of the amount of fluid in our material must be regarded as maximum values as the vagina was not swabbed free of fluid before the daily self-insertion of the tampons.

The amount of semen absorbed by tampon in sexually active women might also be variable. However, inspection of the various cycles indicates that the variations in the amount of fluid collected in women with an extensive coital activity with ejaculation (Subjects 1, 2, 5 and 7) are no greater than those observed in subjects not experiencing coitus (Subjects 3, 4 and 6). Moreover, coitus did not appear to be regularly followed by an increased amount of fluid (see Subjects 5 and 7, Text-figs $1 \mathrm{~h}$ and 2 respectively).

\section{Variation in calcium levels}

The level of calcium in genital fluids has been invoked as a possible influential ion in relation to the motility of spermatozoa (Mann, 1964; Mitchell, Nelson \& Hafez, 1976). The reported level of calcium in cervical fluid, $1.7-3.8 \mathrm{mmol} / 1(68-153 \mu \mathrm{g} / \mathrm{g})$, measured by Kopito, Kosarsky, Sturgis, Liberman \& Schwachman (1973), is much less than the $6.1 \mathrm{mmol} / 1(24-25$ $\mathrm{mg} / 100 \mathrm{ml}$ ) measured in semen by Goldblatt (1935).

We found values of $1-5 \mathrm{mmol} / \mathrm{kg}$ in the vaginal fluids of the 3 certainly ovulating women. There was a clear-cut relation between the amount of fluid collected and the calcium concentration, the greater the amount of fluid, the lower the level of calcium. The mechanism(s) producing the lowering of vaginal calcium is unknown but it may involve the dilution of the vaginal contents rich in calcium by cervical secretion which is poor in calcium. Assuming that the calcium concentration at mid-cycle, around the atime of $\mathrm{BOxulation}$, dis othe optimum for $9: 22 \mathrm{AM}$ 
ejaculated sperm function, then it could be argued that the levels of calcium measured in vaginal secretions during the rest of the cycle may be too high for sperm survival. Excess $\mathrm{Ca}^{2+}$ is claimed to have an injurious effect on sperm motility (Mitchell et al., 1976). However, most estimates, including ours, of calcium in the genital fluids have been obtained by analytical techniques that measure total calcium (bound and unbound). As it is presumably only the free or unbound calcium that influences sperm function, and as genital secretions contain substances such as proteins, polysaccharides and citrate that act to bind the ion, assessments of total calcium in genital fluids may give an unsatisfactory picture of the role of $\mathrm{Ca}^{2+}$.

We thank the "Praktiserende laege i Gentofte, dr. med. August Petersen og laege Thorkil Petersens legat", IPPF for financial support and Birdie Knudsen (Copenhagen) and Andrew Parker (Sheffield) for their excellent technical support. Tampax Ltd kindly supplied the tampons.

\section{References}

Battersby, S. \& Chandler, J.A. (1977) Correlation between elemental composition and motility of human spermatozoa. Fert. Steril. 28, 557-561.

Brown, W.J. (1978) Microbial ecology of the normal vagina. In The Human Vagina, pp. 407-422. Eds E. S. E. Hafez \& T. N. Evans. North Holland Publishing Co., Amsterdam.

Clemetson, C.A.B., Kim, J.K., de Jesus, T.P.S., Mallikarjuneswara, V.R. \& Wilds, J.H. (1973) Human uterine fluid potassium and the menstrual cycle. J. Obstet. Gynaec. Br. Commonw. 80, 553-561.

Documenta Geigy (1973) Scientific Tables, 7th edn, pp. 562-565. Eds K. Diem \& C. Lentner. Geigy Pharmaceuticals, Macclesfield.

Dusitsin, N., Gregoire, A.T., Johnson, W.D. \& Rakoff, A.E. (1967) Histidine in human vaginal fluid. Obstet. Gynec. 29, 125-129.

Edwards, R.G. (1973) Studies on human conception. Am. J. Obstet. Gynec. 117, 587-601.

Edwards, R.G., Talbert, L., Israelstam, D., Nino, H.V. \& Johnson, M.H. (1968) Diffusion chamber for exposing spermatozoa to human uterine secretions. $A m . J$. Obstet. Gynec. 102, 388-396.

Goldblatt, M.W. (1935) Constituents of human seminal plasma. Biochem. J. 29, 1346-1357.

Guerin, J.F. \& Czyba, J.C. (1979) Effects of ions and $\mathrm{K}^{+}: \mathrm{Na}^{+}$ratio on motility and oxygen consumption of human spermatozoa. Arch. Androl. 2, 295-300.

Hilgers, T.W. \& Prebil, A.M. (1979) The ovulation method-vulvar observations as an index of fertility/ infertility. Obstet. Gynec. 53, 12-22.

Huggins, C. (1945) The physiology of the prostate gland. Physiol. Rev. 25, 281-295.

Huggins, C., Scott, W.W. \& Heinen, J.H. (1942) Chemical composition of human semen and of the secretions of the prostate and seminal vesicles. $A m . J$. Physiol. 136, 467-473.

Igarashi, M. (1954) Studies on the cyclic changes in human cervical mucus as well as its crystallization phenomenon. J. Jap. Obstet. Gynec. Soc. 1, 194-202.

Israel, R., Mishell, D.R., Stone, S.C., Thorneycroft, I.H. \& Moyer, D.L. (1972) Single luteal phase serum progesterone assay as an indicator of ovulation. $\mathrm{Am}$. J. Obstet. Gynec. 112, 1043-1046.
Johansson, E.D.B., Larsson-Cohn, U. \& Gemzell, C. (1972) Monophasic basal body temperature in ovulatory menstrual cycles. Am. J. Obstet. Gynec. $113,933-937$.

Kar, A.B., Engineer, A.D., Goel, R., Kamboj, V.P., Dasgupta, P.R. \& Chowdhury, S.R. (1968) Effect of an intrauterine contraceptive device on biochemical composition of uterine fluid. Am. J. Obstet. Gynec. 101, 966-970.

Kopito, L.E., Kosarsky, H.J., Sturgis, S.H., Lieberman, B.L. \& Schwachman, H. (1973) Water and electrolytes in human cervical mucus. Fert. Steril. 24, 499-506.

Lebech, P.E., Svendsen, P.A. \& Østergaard, E. (1970) The effects of small doses of megestrol acetate on the cervical mucus. Int. J. Fertil. 15, 65-76.

Levin, R.J. \& Wagner, G. (1978) Mechanisms for vaginal ion movements in women. J. Physiol., Lond. 284, 172-173P.

Lippes, J., Enders, R.G., Pragay, D.A. \& Bartholomew, W.R. (1972) The collection and analysis of human fallopian tubal fluid. Contraception 5, 85-103.

Mann, T. (1964) The Biochemistry of Semen and of the Male Reproductive Tract. Methuen, London.

Mitchell, J.A., Nelson, L. \& Hafez, E.S.E. (1976) Motility of spermatozoa. In Human Semen and Fertility Regulation in Men, pp. 83-99. Ed. E. S. E. Hafez, C. V. Mosby, Saint Louis.

Nelson, L. (1967) Sperm motility. In FertilizationComparative Morphology, Biochemistry and Immunology, Vol. 1, pp. 27-97. Eds C. B. Metz \& A. Monroy. Academic Press, New York.

Odeblad, E. (1964) Intracavitary circulation of aqueous material in the human vagina. Acta obstet. gynec. scand. 43, 360-368.

Polishuk, W.Z. \& Ron, M. (1976) Detection of ovulation by the water content of vaginal mucus. Israel. J. Med. Sci. 12, 1207-1208.

Pommerenke, W.T. (1946) Cyclic changes in the physical and chemical properties of the cervical mucus. Am. J. Obstet. Gynec. 52, 1023-1029.

Shalgi, R., Kraicer, P.F. \& Sofferman, N. (1972) Gases and electrolytes of human follicular fluid. $J$. Reprod. Fert. 28, 335-340 
Sheth, A.R. \& Rao, S.S. (1962) Potassium levels in human semen with reference to sperm motility. Experientia 18, 324-325.

Spector, W.S. (1956) Handbook of Biological Data, Table 48, p. 59. W. B. Saunders Co., Philadelphia.

Spona, J., Schneider, W.H.F. \& Wacheck, W. (1978) Rascher Radioimmunoassay fur die bestimmung von progesteronserumspiegeln. Wiener klin. Wochenschrift 90, 654-658.

Toyoda, Y. \& Chang, M.C. (1974) Capacitation of epididymal spermatozoa in a medium with high $\mathrm{K} / \mathrm{Na}$ ratio and cyclic AMP for the fertilisation of rat eggs in vitro. J. Reprod. Fert. 36, 125-134.

Wagner, G. \& Levin, R.J. (1978a) Vaginal fluid. In The Human Vagina, pp. 121-138. Eds E. S. E. Hafez \& T. N. Evans. North Holland Publishing Co., Amsterdam.

Wagner, G. \& Levin, R.J. (1978b) Oxygen tension of the vaginal surface during sexual stimulation in the human. Fert. Steril. 30, 50-63.

Received 19 October 1979 